\title{
CMKLR1 Gene
}

National Cancer Institute

\section{Source}

National Cancer Institute. CMKLR1 Gene. NCI Thesaurus. Code C24301.

This gene plays a role in G protein-coupled receptor signal transduction; however, its exact function is unknown. 